\title{
A NEW EPIDURAL CANNULA
}

\author{
BASTL S. SKTNNER, M.D. ${ }^{\circ}$
}

IN ORDER to carry out the procedure of continuous epidural anaesthesia, a cannula has to be passed through a needle, usually 16 gauge, and advanced into the epidural space for a variable distance, depending upon the anaesthetic procedure being carried out. At the present time, two types of cannula are available to anaesthetists. The first consists of vinyl plastic tubing, which is obtainable in bulk. It is cut into suitable lengths, and may or may not be inscribed with suitable markings by the staff of the anaesthetic department; then it is packaged, and finally autoclaved. This method has several disadvantages, such as the time and labour involved in cutting, marking, packaging, and sterilizing. Furthermore, the cut end of the cannula is relatively traumatic to structures within the epidural space. Finally, the material after autoclaving is considered to be unnecessarily stiff, and therefore potentially traumatic. In order to inject local anaesthetic through the cannula, a 24- or 25-gauge needle has to be inserted into the proximal end, and since the lumen of the needle is of necessity smaller than that of the cannula, this adds to the resistance, and to the pressure necessary to inject the local anaesthetic.

The second type of cannula is made of nylon, which is rigid enough to pass through a Tuohy needle, but far more flexible, and therefore less traumatic. It is supplied by the manufacturers packaged singly, and is gamma-ray sterilized. But this cannula suffers from the following disadvantages:

1. The packaging consists of two sealed plastic envelopes, one within the other, the cannula being within the inner envelope. In order to remove the inner envelope, it is necessary to cut through the outer one with scissors, thus risking bacterial contamination of the inner one.

2. The distal end of the cannula has a hard, sharp, point, which is prone to enter the veins in the epidural plexus.

3. Apart from the hole at the tip of the cannula, there is a second hole 8 to 9 $\mathrm{mm}$. proximal to the tip, and the cannula is prone to kink at this place, making it diffcult or impossible to inject fluid through it if the degree of kink is great enough.

4. The marks at the distal end of the cannula are not helpful in inserting an accurate length of cannula into the epidural space.

5. The proximal end of the cannula ends in a dilated portion into which fits a standard Luer syringe; thus it is impossible to remove the Tuohy needle from the cannula for the duration of the anaesthetic procedure.

In the face of the disadvantages of existing types of cannulas, a new cannula has been developed for continuous epidural anaesthesia, having none of the disadvantages of the types previously mentioned. It is made of transparent nylon, and is

'The Queen Elizabeth Hospital, Barbados, W.I. 
soft and flexible, but nevertheless firm enough to pass through a Tuohy needle into the epidural space. Under stress it tends to stretch rather than break. It is gamma-ray sterilized, and therefore the fine properties of the material from which it is made are not altered by the heat of autoclaving. It comes singly packaged in a "peel pack" which can be easily removed without risk of contamination. The tip of the cannula, which is passed into the epidural space, is blunt, and as atraumatic as possible, and has a hole in its end. There is a second hole, $3 \mathrm{~mm}$. from the distal end. With the hole in this position, kinking is impossible with the stresses involved in normal use (Fig. 1). The first mark on the cannula is placed so that it enters the hub of a standard 16-gauge Tuohy needle as the tip of the cannula enters the epidural space. Thereafter there are marks at $1 \mathrm{~cm}$. intervals, so that the anaesthetist can, if he wishes, insert an accurate length of cannula.

A blunt-ended needle of the Luer Lok type is supplied with each cannula, the proximal end of which is slightly dilated to receive it. This needle can be easily removed from the cannula in order to remove the Tuohy needle, and just as easily reinserted, in order to inject the local anaesthetic (Fig. 2). The blunt end of the needle prevents it from piercing the cannula. Since the proximal end of the cannula is dilated to accommodate the needle, the lumen of the latter approximates that of the cannula, thus making for easier injection of the anaesthetic solution.

At the present time, a study is under way to compare the tissue reactivity of nylon and vinyl plastic, and the results will be reported at a later date.

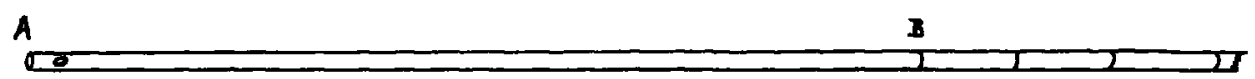

Frgure 1. The distal end of the cannula, showing the terminal hole, the additional hole $3 \mathrm{~mm}$. from the tip, and the first four $1 \mathrm{~cm}$. marks. The distance between $A$ and $B$ equals the length of a standard 16-gauge Tuohy needle.

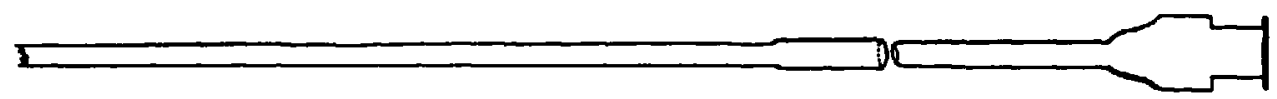

Figure 2. The proximal end of the cannula, showing the dilated portion and the blunt-ended Luer Lok needle.

\section{SUMmary}

An account is given of a new, improved, gamma-ray sterilized, nylon cannula, for continuous epidural anaesthesia, which possesses advantages over existing nylon or vinyl plastic cannulae."

\section{RÉSUMÉ}

Ce travail décrit une nouvelle canule pour anesthésie épidurale continue, canule qui possède les caractéristiques suivants: Elle est fabriquée de nylon

'The new cannula can be obtained from Portland Plastics Ltd., Hythe, Kent, England, and my thanks are due to Mr. A. E. Lloyd-Dodd for his kind help in its development. 
transparent, douce et flexible, et cependant assez ferme pour pénétrer dans l'espace épidural en passant dans une aiguille Tuohy. Sous une poussée exagérée elle a tendance à s'étendre plutôt qu'à se briser. On la stérilise aux rayons gamma, et par conséquent les propriétés délicates du matériel qui la constitue ne sont pas changées par la chaleur de l'autoclave. Elle est livrée en paquetage individuel, et enveloppée de telle sorte qu'on peut la saisir sans la contaminer. Le bout de la canule qu'on introduit dans l'espace épidural est mousse et aussi atraumatique que possible, et il est perforé à son extrémité. Il y a une deuxième ouverture, à trois millimètres du bout. La position de ce deuxième orifice prévient le tortillement dans les conditions normales d'utilisation (Fig. 1). La première marque sur la canule est placée de telle sorte qu'elle arrive à l'entrée de l'aiguille Tuohy 16 au moment où la pointe pénètre dans l'espace épidural. Par la suite, il y a une marque à chaque centimètre; ainsi l'anesthésiste peut, s'il le désire, insérer une longueur précise de canule.

Une aiguille d̀ extrémité mousse, de type "Luer Lok", est fournie avec chaque canule; celle-ci est légèrement dilatée à son extrémité proximale, ce qui facilite l'introduction de l'aiguille. Cette dernière peut être facilement retirée de la canule, afin d'enlever l'aiguille Tuohy, puis replacée, pour injecter l'anesthésique local (Fig. 2). L'extrémité mousse de l'aiguille l'empêche de percer la canule. Puisque l'extrémité proximale de la canule est dilatée pour recevoir l'aiguille, la lumière de cette dernière est à peu près de même calibre que celle de la canule, ce qui facilite l'injection de la solution anesthésique. 